\title{
Ophthalmic Artery Doppler in Hypertensive pregnancies: one small vessel, many possibilities
}

\author{
Angélica Diniz ${ }^{1}$ and Maria Marta Paes ${ }^{1}$ \\ ${ }^{1}$ Federal University of Uberlândia - Umuarama Campus
}

February 14, 2022

\section{Hosted file}

BJOG.docx available at https://authorea.com/users/460389/articles/556411-ophthalmic-arterydoppler-in-hypertensive-pregnancies-one-small-vessel-many-possibilities 